\title{
A Study on Importance and Role of Irrigation and Hydropower Plant Operation in Integrated River Basin Management
}

\author{
Cengiz Koç \\ Department of City and Regional Planning, Faculty of Architecture, Muğla Sıtkı Koçman University, Muğla, Turkey \\ Email: cengizko9@gmail.com
}

How to cite this paper: Koç, C. (2017) A Study on Importance and Role of Irrigation and Hydropower Plant Operation in Integrated River Basin Management. Computational Water, Energy, and Environmental Engineering, 6, 1-10.

http://dx.doi.org/10.4236/cweee.2017.61001

Received: September 21, 2016

Accepted: November 18, 2016

Published: November 21, 2016

Copyright $\odot 2017$ by author and Scientific Research Publishing Inc. This work is licensed under the Creative Commons Attribution International License (CC BY 4.0).

http://creativecommons.org/licenses/by/4.0/

(c) (i) Open Access

\begin{abstract}
In this study, 16 irrigation schemes (Baklan, Irgıllı, Sütlaç, Çal, Çürüksu, Nazilli, Sarayköy, Pamukkale, Sultanhisar, Akçay, Aydın, Topçam, Karpuzlu, Işıklı, Gümüşsu ve Söke) having 166,381 hectares, built by State Hydraulic Works (DSI), and operated by participatory irrigation managements, and 14 hydroelectric power plants (HPP) operated and built on dams, canals and rivers by the public and private sectors are examined in the Büyük Menderes basin which is an important basin in terms of the agriculture, energy and ecology projects. Integrated basin management practices and the importance and role of irrigation and hydropower plant operation in integrated basin management, how it should be, optimal use of available water resources for irrigation and hydroelectric power plant operation, irrigation relationship with canal hydropower plants, operated under integrated basin management of irrigation and hydropower plants, environment and the ecological effects have been studied, and integrated basin management with the existing basin management conditions in terms of hydropower plant and irrigation operation on the basis of data of 2015 have been compared, reached important conclusions, and made recommendations on the subject.
\end{abstract}

\section{Keywords}

Hydropower Plant, Irrigation, Integrated Basin Management, Operation, Büyük Menderes Basin, Turkey

\section{Introduction}

Integrated River Basin Management (IRBM), dealing with surface and ground water, soil and water resources in the basin boundaries, relationship between upstream and downstream of the basin, the relationship water using for different places and different purposes, and management, the determination of the basic relationships with water 
ecosystems in need of water, and to ensure cooperation between these relationships mentioned is to establish the legal and institutional mechanisms. When considering the concept of sustainable development, IRBM offers the most convenient way and assurance to ensure multi-purpose use of water systems reacting environmental functions for present and future generations.

The concept of integrated basin water management is considered the possibilities cycle, re-use, water demand, benefits, relations between human activities and the natural environment that supports the deterioration in water quality due to pollution [1]. Integrated river basin management, according to the traditional water management is to use of a broader perspective, and includes pollution control and prevention, land use planning, agriculture policy, erosion control, environmental management and other political elements.

Integrated management is described as the planning of activities including management and use of natural resources existence of social, political, economic and institutional factors, taking into account for sustainable management and planned of natural resources in the basin [2]. With integrated basin management, conservation and sustainable use of the basins, which is effective in all institutions, policies and activities of the authorities and individuals, are given the provision of effective and regular coordination [3]. Hydroelectric production meets $19 \%$ of the world's energy requirements and constitutes one of the major driving forces behind the construction of the 45,000 large dams available in the world [4]. Electricity generation is very small effect on the amount of water (limited losses by evaporation from dams), but the release time of water for electric production according to demand curve is to change the hydrograph of river flows.

This situation is the cause of conflicts between the downstream user including ecological systems and hydroelectric, irrigation [5]. Integrated river basin management is composed of four independent elements. These are legal-institutional framework, planning, operation management and analytical support [6]. Each element reveals fundamental operable above the other. Four elements are important for integrated river basin management; however, management, because it directly affects the river basin is becoming much more important.

In this study, integrated basin management practices, the importance and role of irrigation and hydropower plant operation in integrated basin management, how it should be, optimal use of available water resources for irrigation and hydropower plant operation, irrigation relationship with canal hydropower plants, operated under integrated basin management of irrigation and hydropower plants, environment and the ecological effects have been studied.

\section{Material and Method}

Büyük Menderes river basin is in the Western part of the Anatolian peninsula; southwest of Turkey, between $37^{\circ} 6^{\prime}-38^{\circ} 55^{\prime}$ North and $27^{\circ} 36^{\prime}-30^{\circ} 36^{\prime}$ East (Figure 1 ). The border of the river basin constitutes $3.2 \%$ of surface area of Turkey, and covers a part of Aydın, Uşak, Denizli, Muğla, Afyon, Isparta, Burdur and Izmir provinces. The river is the longest river in the Aegean Region of Turkey with $584 \mathrm{~km}$ length. The river is fed 


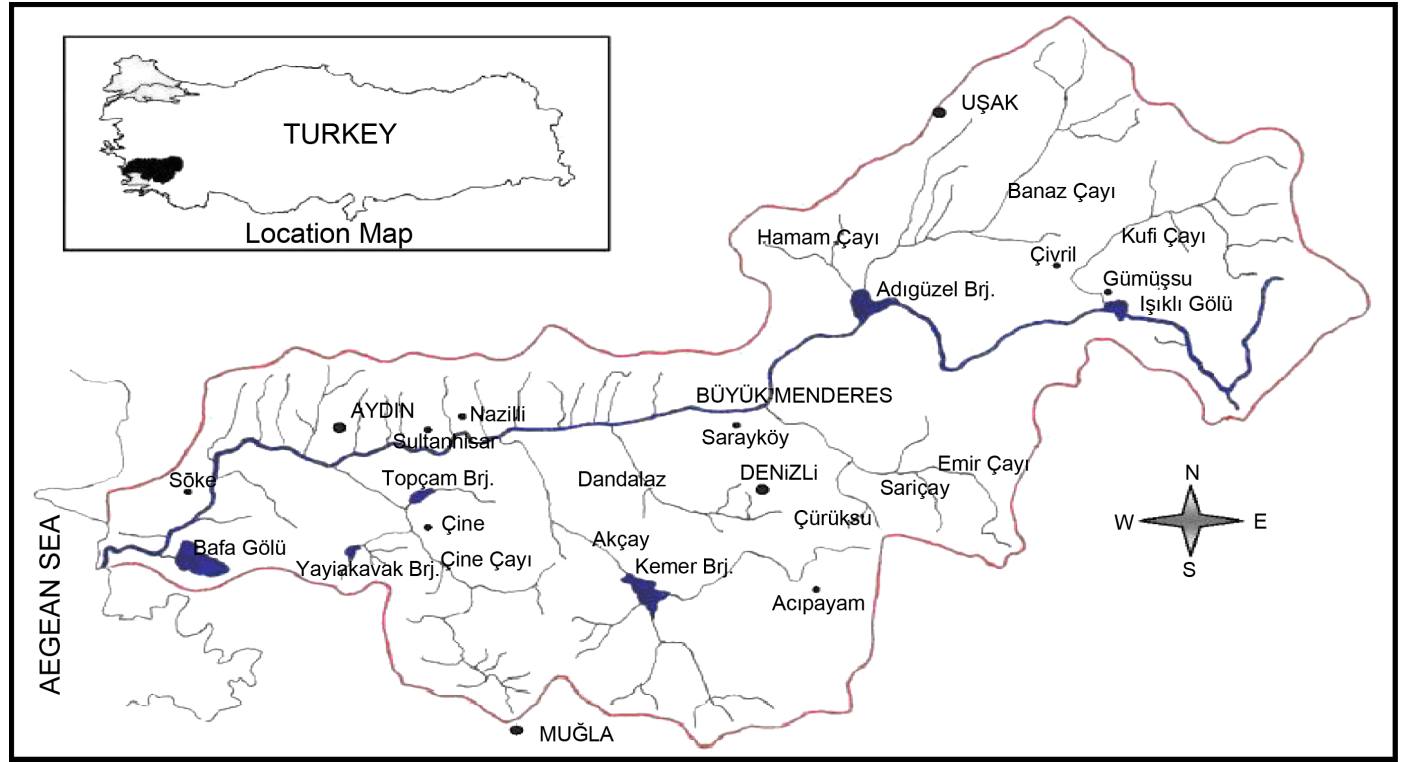

Figure 1. The location of Büyük Menderes Basin in Turkey.

by a number of streams in the basin. In summer, a great number of these tributaries dry. In Büyük Menderes Basin, effects of both Mediterranean and continental climates are visible. The average flow rate of Büyük Menderes River is $110 \mathrm{~m}^{3} \cdot \mathrm{s}^{-1}$ [7]. Basinacross, average annual rainfall is $650 \mathrm{~mm}$; more than $70 \%$ of the precipitation falls in winter and spring. Annual average water potential of the Büyük Menderes river is 3 billion 30 million $\cdot \mathrm{m}^{3}$, of this amount, $2.7 \mathrm{billion} \cdot \mathrm{m}^{3}(90 \%)$ is controlled by storage facilities (dams) built in the basin. The most important storage facilities in Büyük Menderes basin are Isıklı Lake, Adıgüzel, Cindere, Gökpınar, Kemer, Çine, İkizdere, Yenidere, Topçam and Karpuzlu dams. Approximately $90 \%$ of the basin water resources, agriculture, the rest of the potable, tourism, industry and ecology are used.

Project irrigation area, type of irrigation schemes, water intake structure, the date of operation, water supply way of irrigation schemes located in Great Menderes basin are given in Table 1 [8]. All irrigation schemes of the basin are managed by Water User Associations. Land use in the basin consists of $44 \%$ agricultural, 33\% semi-natural areas, $20 \%$ forested, $2 \%$ rural and urban areas and $1 \%$ in surface waters.

The amount of water used per hectare irrigation rate and irrigation efficiency in the irrigation schemes studied is calculated by the computer program Excel. The amount of water used per hectare $\left(\mathrm{m}^{3} \cdot \mathrm{ha}^{-1}\right)$ is calculated the total amount of water taken into the scheme divided by total irrigated area; irrigation rate (\%), the actual irrigated area divided by the net irrigation; irrigation efficiency (\%), total net water consumption of the crop grown in irrigated area divided by the total amount of water taken into the scheme. 14 HPPs in Büyük Menderes basin were built and under operation services (Figure 2).

Names of Hydroelectric Power Plant operated, where it was built, date of operation, operating organizations, type of HPP, where HPP was built, total installed power (MW), project production values $\left(\mathrm{GWh} \cdot \mathrm{year}^{-1}\right)$ and rates of production realized are given in Table 2. Overall, the result of the new legislation at the beginning of the 2000s, on project approvals and licenses granted canal or river-off HPP facilities by the DSI 
Table 1. Characteristics of the Büyük Menderes basin irrigation schemes [11].

\begin{tabular}{|c|c|c|c|c|c|c|c|c|c|}
\hline \multirow{2}{*}{$\begin{array}{l}\text { Name of } \\
\text { irrigation scheme }\end{array}$} & \multirow{2}{*}{$\begin{array}{c}\text { Date of } \\
\text { operation }\end{array}$} & \multicolumn{2}{|c|}{ Irrigation area (ha) } & \multicolumn{3}{|c|}{ Type of irrigation scheme } & \multicolumn{2}{|c|}{ Water supply type } & \multirow{2}{*}{ Water intake structure } \\
\hline & & Brut & Net & Classic & Flume & Pipe & Gravity & Pump & \\
\hline Pamukkale & 1946 & 10.556 & 8.593 & Classic & & & & Pump & Pump Sta. \\
\hline Sarayköy & 1961 & 10.582 & 8.245 & Classic & & & Gravity & & Regulator \\
\hline Nazilli & 1943 & 18.485 & 15.000 & Classic & Flume & & Gravity & & Regulator \\
\hline Sultanhisar & 1998 & 7.360 & 4.740 & Classic & & Pipe & Gravity & & Regulator \\
\hline Akçay & 1965 & 18.493 & 14.900 & Classic & Flume & & Gravity & & Regulator \\
\hline Aydın & 1991 & 18.500 & 16.500 & Classic & Flume & & Gravity & Pump & Regulator \\
\hline Söke & 1981 & 29.135 & 26.000 & Classic & & & Gravity & & Regulator \\
\hline Topçam & 1985 & 4.980 & 4.300 & Classic & Flume & & Gravity & Pump & Dam + Pump \\
\hline Karpuzlu & 1998 & 3.600 & 2.800 & Classic & & Pipe & Gravity & & Dam \\
\hline Çürüksu & 1986 & 12.250 & 9.212 & Classic & Flume & & Gravity & & Regulator \\
\hline Irgillı & 1964 & 5.410 & 2.900 & Classic & & & Gravity & & Regulator \\
\hline Sütlaç & 1996 & 3.000 & 2.880 & Classic & & & Gravity & Pump & Regulator \\
\hline Baklan & 1991 & 47.400 & 42.421 & Classic & Flume & Pipe & & Pump & Pump Sta. \\
\hline Gümüşsu & 1992 & 2.200 & 1.600 & Classic & & & & Pump & Pump Sta. \\
\hline Çal & 1996 & 1.840 & 1.730 & Classic & Flume & & Gravity & & Regulator \\
\hline Işıklı & 1965 & 2.700 & 1.660 & Classic & & & Gravity & & Regulator \\
\hline
\end{tabular}

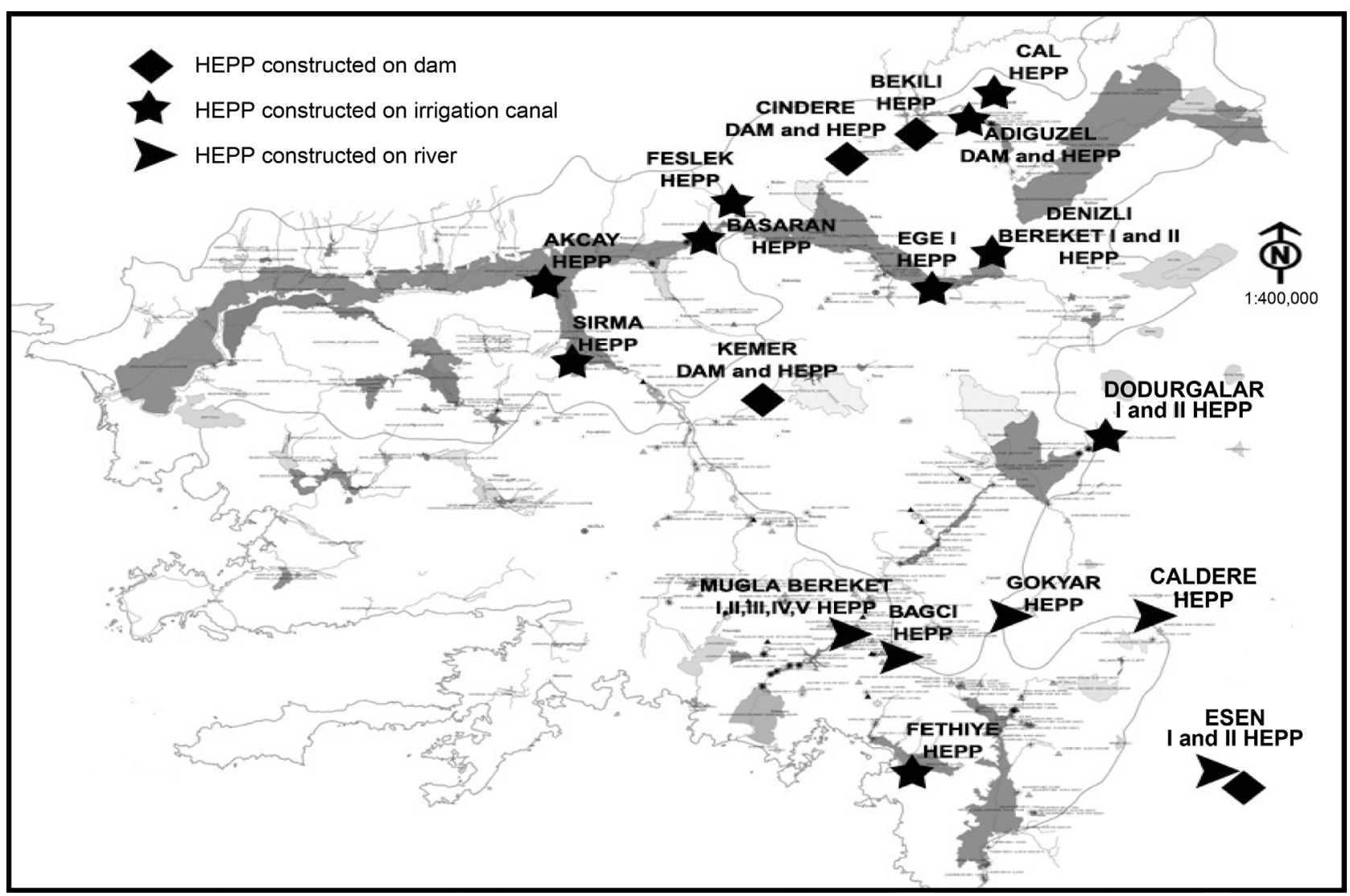

Figure 2. Hydroelectric power plants operated in the Büyük Menderes Basin. 
Table 2. Characteristics of the Büyük Menderes Basin Hydroelectric power plants.

\begin{tabular}{|c|c|c|c|c|c|c|c|c|}
\hline $\begin{array}{l}\text { Name of } \\
\text { HPP }\end{array}$ & Province & $\begin{array}{c}\text { Date of } \\
\text { operation }\end{array}$ & $\begin{array}{c}\text { Name of operation } \\
\text { organization }\end{array}$ & $\begin{array}{c}\text { Location of } \\
\text { HPP }\end{array}$ & $\begin{array}{l}\text { Total installed } \\
\text { capacity MW }\end{array}$ & $\begin{array}{l}\text { Project production } \\
\text { value GWh.year }\end{array}$ & $\begin{array}{l}\text { Production year of } \\
2015 \mathrm{GWh} \cdot \text { year }^{-1}\end{array}$ & $\begin{array}{l}\text { Realization } \\
\text { rate } \%\end{array}$ \\
\hline Feslek & Aydın & 2004 & $\begin{array}{c}\text { Bereket Energy } \\
\text { Production Company }\end{array}$ & $\begin{array}{l}\text { Nazilli Right Bank } \\
\text { Irrigation Channel }\end{array}$ & 8.84 & 41.00 & 18.56 & 45 \\
\hline Başaran & Aydın & 2006 & $\begin{array}{c}\text { Ekin Energy } \\
\text { Production Company }\end{array}$ & $\begin{array}{l}\text { Nazilli Left Bank } \\
\text { Irrigation Channel }\end{array}$ & 0.60 & 4.27 & 0.91 & 21 \\
\hline Akçay & Aydın & 2009 & $\begin{array}{c}\text { Akçay Energy } \\
\text { Production Company }\end{array}$ & $\begin{array}{l}\text { Akçay Irrigation } \\
\text { Main Channel }\end{array}$ & 28.78 & 94.88 & 78.46 & 82 \\
\hline Sirma & Aydın & 2009 & $\begin{array}{c}\text { Beyobası Energy } \\
\text { Production Company }\end{array}$ & $\begin{array}{c}\text { Akçay Irrigation } \\
\text { Main Channel }\end{array}$ & 5.88 & 23.20 & 20.23 & 89 \\
\hline Kemer & Aydın & 1958 & EÜAŞ (Public) & Kemer Dam & 48.00 & 143.00 & 122.21 & 85 \\
\hline Cindere & Denizli & 2008 & $\begin{array}{c}\text { Entek Energy } \\
\text { Production Company }\end{array}$ & Cindere Dam & 28.50 & 88.10 & 53.31 & 61 \\
\hline Adıgüzel & Denizli & 1990 & EÜAS (Public) & Adıgüzel Dam & 62.00 & 280.00 & 128.53 & 46 \\
\hline Çal & Denizli & 2001 & $\begin{array}{c}\text { Limak Energy } \\
\text { Production Company }\end{array}$ & $\begin{array}{l}\text { Çal Irrigation } \\
\text { Main Channel }\end{array}$ & 2.20 & 11.75 & 12.90 & 110 \\
\hline Bereket I-II & Denizli & 1998 & $\begin{array}{c}\text { Bereket Energy } \\
\text { Production Company }\end{array}$ & $\begin{array}{l}\text { Çürüksu Right } \\
\text { Bank Channel }\end{array}$ & 3.15 & 12.00 & 13.05 & 109 \\
\hline Dodurgalar I-II & Denizli & 2004 & $\begin{array}{c}\text { Elta Energy } \\
\text { Production Company }\end{array}$ & $\begin{array}{l}\text { Dodurgalar } \\
\text { I-II Channel }\end{array}$ & 4.14 & 12.00 & 11.66 & 97 \\
\hline Ege I & Denizli & 2009 & $\begin{array}{c}\text { Denizli Energy } \\
\text { Production Company }\end{array}$ & $\begin{array}{l}\text { Çürüksu Left } \\
\text { Bank Channel }\end{array}$ & 0.92 & 4.38 & 3.11 & 71 \\
\hline Bekilli & Denizli & 1954 & Bekilli municipality & $\begin{array}{l}\text { Çal Irrigation } \\
\text { Main Channel }\end{array}$ & 0.33 & 0.40 & 0.33 & 83 \\
\hline
\end{tabular}

(State Hydraulic Works) and the Energy Market Regulatory Authority (EMRA), private sector investment especially starting from 2007 showed a large increase. The first stage of the application and licensing process for HPP facilities is delivered to DSI the feasibility report prepared for the project in question. Reviewed of reports by the DSI and with accepted companies the Water Use Right Agreement is signed and sent to EMRA to receive electricity generation license. After the receiving of Environmental Impact Assessment (EIA) Positive Certificate and HPP construction license, HPP facility is established and operated [9] [10]. To enable comparisons across countries and time, local unit's currencies were converted to international standard units and constant US\$ dollar prices.

\section{Conclusions}

Irrigation schemes and hydroelectric power plants constructed and operated in Büyük Menderes basin have been assessed within the integrated basin management, and the following conclusions have been reached. Irrigation water for irrigation schemes is taken from storage facilities constructed in the basin. Considering the basin integrity before the irrigation season, the current amount of water in the water storage facilities, the maximum and minimum turbine flow of power plants and positional relationship with each other of irrigation schemes, General Basin Irrigation Plan is to be prepared and, the amount of water to be used during the season of each irrigation scheme is to be 
calculated. For the year 2015 that the study was conducted in the irrigation scheme, irrigation water used in unit area (ha) amount, net irrigation water requirements of plants, irrigation rate, irrigation efficiencies, total irrigation water used in the scheme, the total production value and average production values belonging to the irrigation schemes is given in Table 3. Settlement system and position of irrigation schemes operated according to the principle of integrated river basin management are arranged from downstream to upstream in the basin. Water, returning from an irrigation scheme is the water source of the other scheme. Total net irrigation area of 16 irrigation schemes operated in the basin is 166,381 hectares; total irrigated area is calculated as 141,449 hectares. Approximately $85 \%$ of net irrigation area is irrigated virtually. Irrigation water used unit area (ha) varies 3380 to $14,607 \mathrm{~m}^{3} \cdot \mathrm{ha}^{-1}$ in the basin irrigation schemes. Showing differences of irrigation water used unit area (ha) in the basin irrigation schemes stem from differences of soil structure in their irrigation area, climatic conditions, crop pattern, irrigation season length, field irrigation methods used in the irrigation area, and the inability to serve irrigation management organizations engaged in water distribution. Therefore, using an average value in calculations is not appropriate. Irrigation rate varies between $37 \%$ and $146 \%$.

Irrigation rates in irrigation scheme studied vary quite a different and wide range. [12], the irrigation schemes operated by State Hydraulic Works the in the years 1979 to 1990, irrigation rates show a quite different ranging from $117 \%$ to $32 \%$. Irrigation rates,

Table 3. The calculated 2015 data of Büyük Menderes basin irrigation schemes.

\begin{tabular}{|c|c|c|c|c|c|c|c|c|c|}
\hline \multirow{2}{*}{$\begin{array}{l}\text { Name of } \\
\text { irrigation } \\
\text { scheme }\end{array}$} & \multicolumn{7}{|c|}{ Data of 2015 calculated regarding the studied basin irrigation schemes } & \multirow{2}{*}{$\begin{array}{l}\text { Total } \\
\text { production } \\
\text { value } \\
\left(\text { \$US·year }{ }^{-1}\right)\end{array}$} & \multirow{2}{*}{$\begin{array}{c}\text { Average } \\
\text { production } \\
\text { value }\left(\$ U S \cdot \mathrm{da}^{-1}\right)\end{array}$} \\
\hline & $\begin{array}{l}\text { Net irrigation } \\
\text { area (ha) }\end{array}$ & $\begin{array}{l}\text { Actual } \\
\text { irrigated } \\
\text { area (ha) }\end{array}$ & $\begin{array}{c}\text { Water use per } \\
\text { unit area } \\
\left(\mathrm{m}^{3} \cdot \mathrm{ha}^{-1}\right)\end{array}$ & $\begin{array}{l}\text { Crop net irrigation } \\
\text { water requirement } \\
\qquad\left(\mathrm{m}^{3} \cdot \mathrm{ha}^{-1}\right)\end{array}$ & $\begin{array}{l}\text { Irrigation } \\
\text { rate }(\%)\end{array}$ & $\begin{array}{c}\text { Irrigation } \\
\text { efficiency (\%) }\end{array}$ & $\begin{array}{l}\text { Total water used } \\
\left(\mathrm{m}^{3} \cdot \text { year }^{-1}\right)\end{array}$ & & \\
\hline Aydin & 18,500 & 21,992 & 6944 & 3573 & 119 & 51 & $152,710,000$ & $36,583,968$ & 175 \\
\hline Söke & 26,000 & 31,009 & 8374 & 4639 & 119 & 55 & $259,670,000$ & $76,892,503$ & 291 \\
\hline Sarayköy & 8245 & 12,012 & 11,072 & 4496 & 146 & 41 & $133,000,000$ & $36,254,290$ & 355 \\
\hline Pamukkale & 8593 & 5292 & 7937 & 4157 & 62 & 52 & $42,000,000$ & $9,612,685$ & 237 \\
\hline Nazilli & 15,000 & 16,075 & 12,071 & 6442 & 107 & 54 & $193,180,000$ & $41,790,625$ & 274 \\
\hline Sultanhisar & 4740 & 3014 & 11,077 & 6447 & 64 & 59 & $33,180,000$ & $11,380,395$ & 396 \\
\hline Akçay & 14,900 & 12,306 & 10,642 & 5055 & 83 & 48 & $130,970,000$ & $38,341,983$ & 342 \\
\hline Karpuzlu & 2750 & 1161 & 12,997 & 3161 & 42 & 24 & $15,090,000$ & $2,111,517$ & 171 \\
\hline Topçam & 4300 & 1578 & 14,607 & 4081 & 37 & 28 & $23,050,000$ & $3,185,899$ & 207 \\
\hline Çürüksu & 9212 & 9473 & 10,239 & 4437 & 103 & 43 & $96,990,000$ & $28,944,613$ & 346 \\
\hline Işıklı & 1650 & 1550 & 6932 & 4573 & 94 & 66 & $10,750,000$ & $7,852,332$ & 506 \\
\hline Gümüşsu & 1600 & 1000 & 3380 & 4940 & 63 & - & $3,380,000$ & $4,369,722$ & 436 \\
\hline Irgillı & 3920 & 1805 & 12,535 & 4271 & 46 & 34 & $10,750,000$ & $3,577,514$ & 198 \\
\hline Sütlaç & 2820 & 1672 & 5353 & 4418 & 59 & 83 & $8,950,000$ & $4,723,369$ & 282 \\
\hline Çal & 1730 & 675 & 7403 & 4370 & 39 & 59 & $5,000,000$ & $3,324,734$ & 341 \\
\hline Baklan & 42,421 & 20,835 & 5915 & 4174 & 49 & 70 & $123,240,000$ & $56,538,502$ & 271 \\
\hline Total & 166,381 & & & & & & $1,241,910,000$ & $365,484,651$ & \\
\hline
\end{tabular}


actualized between $146 \%$ and $37 \%$ in the basin irrigation schemes as well as in other irrigation schemes operated in our country show quite wide and different distribution. Irrigation ratios are realized at high levels in the irrigation schemes that cotton, vegetables and citrus are grown extensively. Reasons of the low irrigation rate in the irrigation schemes are the scheme physical deficiencies, lack of water resources, and no irrigation of grain sowing areas. In order to increase irrigation rate in the irrigation scheme, it is increasing proportionally with the increase of production value. Low irrigation rates in the irrigation schemes lead to a reduction of the value of project production.

Irrigation efficiency which is an indicator whether used effective in line with the requirements of the water in the irrigation scheme, varies between $24 \%$ and $70 \%$. Irrigation efficiency is the rate of meet the requirements of the existing water resources. Plasquellec et al. (1990) stated that Asia, Africa and in their study in some of the largerscale gravity irrigation schemes in Latin America project, irrigation efficiencies vary between $26 \%$ and $70 \%$, and often close to $40 \%$ [13]. Irrigation efficiencies of irrigation schemes studied are also consistent with these values. Irrigation efficiency is directly related to the amount of water taken into the scheme. Irrigation efficiency increase resulting from the use of technology in the basin irrigation scheme is not seen too much. The total amount of water used in the basin irrigation scheme is $1,241,910,000$ $\mathrm{m}^{3} \cdot$ year $^{-1}$, which is about half of the basin water resources used for irrigation. The total production value obtained by the cultivation of the plants in irrigation schemes is actualized as $365,484,651$ \$US.year ${ }^{-1}$. Production value obtained per unit area in the irrigation scheme ranges between 171 and $506 \$ \mathrm{US} \cdot \mathrm{da}^{-1}$, and average production value of per unit area is calculated as $302 \$ \mathrm{US} \cdot \mathrm{da}^{-1}$. The average production value of unit water in the examined basin irrigation schemes is calculated as $0.40 \$ \mathrm{US} \cdot \mathrm{m}^{-3}$. The highest production value of unit water is realized Gümüşsu, Işıklı, Çal, Sütlaç, Baklan and Irgıllı irrigation schemes; the calculated values are $1.29,0.73,0.66,0.53,0.47$ and $0.33 \$ \mathrm{US}^{-\mathrm{m}^{-3}}$ respectively. Other irrigation schemes range 0.14 to $0.30 \$ \mathrm{US} \cdot \mathrm{m}^{-3}$. The data on project production value and production values in year of 2015 of hydroelectric power plants operated in the basin are presented in Table 2. Realization rate of energy production based on the project production value of HPPs ranged from $21 \%$ to $110 \%$.

Actual production values are realized quite different and wide range. Total energy amount that 14 hydroelectric power plants operated and constructed in the basin produced in 2015 is $463.26 \mathrm{GWh} \cdot \mathrm{year}^{-1}$. The total annual production capacity of the HPPs is $714.98 \mathrm{GWh} \cdot \mathrm{year}^{-1}$ and $65 \%$ of production rate. $35 \%$ of the total amount required to produce is not generated for various reasons. The most important factors that prevent reaching the project production capacity of the studied hydroelectric project; deficiencies in water supply, fast and inadequate feasibility study, the length or shortness of the irrigation period, incorrect selection of turbine capacity, not overlap temporally full of energy production and irrigation, at times increase of energy demand due to the irrigation, maximum level of energy is not produced, can be listed. Energy of per unit water released from Adigüzel dam in the basin is to be taken three times at Adigüzel dam, Entek dam, and Feslek/Başaran canal HPPs. After the completed Yenice HPP construction will be taken four times. Energy of water released from the Kemer dam is taken three times at Kemer dam, Sirma and, including Akcay HPPs. Efficient water use and 
optimum energy production that HPPs studied is linked or above the irrigation schemes; Basin General Irrigation Scheduling should be prepared with a technical study by stakeholder used water and operation stage should be carried out with the same care and stakeholders. Total production value of energy derived from hydroelectric power plants is calculated as 33,918,139 $\$$ US $\cdot$ year $^{-1}$ (average electricity sales price 7.32 cen$\mathrm{tUS} \cdot \mathrm{kWh}^{-1}$ ). Unit water production value of hydroelectric power plants could not be assessed because of the amount of water used cannot be determined reliably.

Total production value obtained from irrigation and hydroelectric production is realized as $399,402,790$ \$US. The production value derived from agricultural production depends on irrigation is higher than obtained from energy. Especially, examined basin irrigation schemes and hydroelectric power plants built in conjunction, as they run together, the amount of water used should be planned so as to make optimum benefits from both sectors.

\section{Recommendations}

Recommendations for operation at the desired level with irrigation systems and hydroelectric power plants in the examined basin are given below.

Dry period being the lack of water resources, managers of the irrigation system should use simulation models and irrigation programs to provide assistance to water users as Basin General Irrigation Plan is prepared.

In order to save water and improve field irrigation efficiency, the using of pressure field irrigation systems (sprinkler, drip) should be expanded in medium pressure closed (pipe) systems built by DSI.

Water-saving irrigation techniques to reduce amount of water used per unit of land should be used and irrigation wage policy, encouraging water users should be determined in the examined basin irrigation schemes. Focusing on the amount of water used in irrigation charge methods (volume, time or number of irrigation) should be identified. This will increase the amount of water used in hydroelectric power plants, the management in the preparation of the necessary plans for the hydroelectric operations and irrigation will provide the necessary flexibility. [14], South Sri Lanka are reported the amount of water used per unit area is higher than the standard, this stem from deep infiltration that occurs in agricultural areas, incompetence of the staff with the current water management organization, the use of continuous flow operation method in the period when there is plenty of water.

Hydroelectric Power Plant projects to be developed in the areas should be planned to the integrated river basin management. Integrated basin planning should be established by including representatives of various professional disciplines, local governments and civil society organizations.

Turbine flow used in the operation of hydroelectric power plants should be planned to overlap with the needed flow for irrigation. The water released from dams is taken primarily energy in the irrigation process, and then used in irrigation services. Determining the flow rate to be used in Basin General Irrigation Planning prepared with the participation of stakeholders in the basin, the minimum and maximum turbine flow of dam and channel hydroelectric plants should be taken into consideration [15]. Ap- 
proaches based sector for water resources (only irrigation/energy) were effective in the past and still continues its activities. This type of approach leads to division and lack of coordination to the development and management of resources [16]. All planning to be made related to water resources in the basin; To be determined the present water potential and to be able to do the correct calculations of future, data of collected with appropriate method and presented to service of the user should be based.

In the preparation phase of the hydroelectric power plant projects in the basin; the people living in the area, the river inside live life, the water requirement of flora and fauna, sustainability of ecological systems, degradation status of forest, pasture, and in land, region-specific facility type selection, geological, topographic, climatic conditions of the facility areas, projects social and cultural effects, should be adequately assessed.

Early detection of regional water needs, to be regulated in a position to prevent the use of the water, to arrange conditions such as unwillingness to produce at the same time of upstream and downstream hydroelectric power plants, to ensure the upstream-downstream relations and control of water; necessary work and basin management system must be planned.

National methods for the determination of water released into the river bed from HPP to ecological should be developed. Determining this method, its own characteristics and characteristics of the surrounding ecosystem of each stream should be considered and must be based on scientific studies. Timing of release of life water and which institutions will control and enforcement mechanisms should be clarified.

\section{References}

[1] Teodosiu, C., Barjoveanu, G. and Teleman, D. (2003) Sustainable Water Resources Management 1. River Basin Management and the EC Water Framework Directive. Environmental Engineering and Management Journal, 2, 377-394.

[2] He, D.W. and Chen, J.S. (2001) Issues, Perspectives and Need for Integrated Watershed Management in China. Environmental Conservation, 28, 368-377.

[3] UN (2006) Water a Shared Responsibility, UNESCO Publishing, World Water Development Report 2.

[4] WCD (World Commission on Dams) (2000) Dams and Development: A New Framework for Decision-Making. Earthscan, London.

[5] Briscoe, J. (1999) The Financing of Hydropower, Irrigation and Water Supply Infrastructure in Developing Countries. Water Resources Development, 15, 459-491. https:/doi.org/10.1080/07900629948718

[6] Moeset, E., Van Beek, Bouman, E., Hez, E. and Savenije, H. (1999) River Basin Management and Planning. Keynote Paper for the International Workshop on River Basin Management, Hague.

[7] Anonymous (1994) Büyük Menderes Havzası I. Merhale Planlama Raporu. Bayındırlık ve İskân Bakanlığı. DSİ Genel Müdürlüğü, XXI. Bölge Müdürlüğü, Aydın, 235s.

[8] Anonymous (2007) DSİ Tarafından İnşa Edilen Sulama Şebekeleri İzleme ve Değerlendirme Raporu. DSİ Genel Müdürlügü, DSİ XXI. Bölge Müdürlüğü, Aydın.

[9] Avcı, İ. (2008) Hedefler, Beklentiler ve Uygulamadaki Gerçekler. Türkiye'de Stratejik Bir Kaynak Olan Su ve Hidroelektrik Potansiyelin Değerlendirilmesi ve Yönetilmesinde Yeni Küresel Yaklaşımlar. Mühendislikte, Mimarlıkta ve Planlamada Ölçü,

[10] EÜAŞ (2008) Özel Sektörün Hidrolik Santral Yapma Aşamaları. Elektrik Üretim Anonim 
Şirketi. http://www.euas.gov.tr/

[11] Anonymous (1997-2014) Sulama Şebekeleri Değerlendirme Raporları. Orman ve Su İşleri Bakanlığı, Devlet Su İşleri Genel Müdürlügü, DSİ XXI. Bölge Müdürlüğü, Aydın.

[12] Erözel, Z. and Alibiglouei, H.M. (1991) Devlet Sulama Şebekelerinde Sulama Oranları. AÜ. Ziraat Fakültesi Yayınları 1219, Bilimsel Araştırma ve inceleme: 668, Ankara, 17s.

[13] Rao, P.S. (1993) Review of Selected Literature on Indicators of Irrigation Performance. International Irrigation Management Institute, Colombo, 75 p.

[14] Molle, F., Jayakody, P., Ariyaratne, R. and Somatilake, H.S. (2005) Balancing Irrigation and Hydropower: Case Study from Southern Sri Lanka. International Water Management Institute, Research Report, 38 p.

[15] Koç, C., Özdemir, K. and Fayrap, A. (2010) Entegre Nehir Havza Yönetiminde Sulama İşletme Hizmetlerinin Yeri ve Önemi Üzerine Büyük Menderes Havzasında Yürütülen Bir Çalışma. I. Ulusal Sulama ve Tarımsal Yapılar Sempozyumu 27-29 Mayıs, Kahraman Maraş, Bildiriler Kitabı, 187-200.

[16] Cap-Net (2008) Performance and Capacity of River Basin Organizations, Cross-Case Comparison of Four RBOs.

http://cap-net.org/sites/cap-netorg/files/RBO\%20performance.doc

Submit or recommend next manuscript to SCIRP and we will provide best service for you:

Accepting pre-submission inquiries through Email, Facebook, LinkedIn, Twitter, etc.

A wide selection of journals (inclusive of 9 subjects, more than 200 journals)

Providing 24-hour high-quality service

User-friendly online submission system

Fair and swift peer-review system

Efficient typesetting and proofreading procedure

Display of the result of downloads and visits, as well as the number of cited articles

Maximum dissemination of your research work

Submit your manuscript at: http://papersubmission.scirp.org/

Or contact cweee@scirp.org 